\title{
The Relationship between Agency Cost and Corporate Performance among Manufacturing Companies in Malaysia
}

\author{
Ahmad Rizal Mazlan ${ }^{1}$, Afiruddin Tapa ${ }^{2 *}$, Nasaruddin Md Yusoff ${ }^{1}$, Ali Badron Mokhtar ${ }^{3}$ \\ 1 Universiti Utara Malaysia Kuala Lumpur \\ 2 School of Economics, Finance and Banking, Universiti Utara Malaysia \\ ${ }^{3}$ Islamic Business School, Universiti Utara Malaysia
}

\begin{abstract}
The relationship between agency cost and corporate performance of manufacturing companies is examined in this study. The sample of this study is based on companies listed in Bursa Malaysia for the period from 2011 to 2016. A regression analysis was done and corporate performance is regressed against the predictor variables which where leverage, size, growth, expense and efficiency. Data for both the dependent and predictor variables were obtained from Bursa Malaysia. This study found that in the model, three out of five proxy of agency costs are significantly related to corporate performance which measured by return on equity (ROE). The three variables which significantly related to corporate performance (ROE) are efficiency, leverage and size with $p$-value $0.0226,0.0002$ and 0.0002 respectively as per table 4.5. The other two variables found that not significantly related to corporate performance (ROE) which are company growth and expense with $\mathrm{p}$-value 0.6915 and 0.3871 respectively. Hence the study found that agency cost to be significantly related to corporate performance.
\end{abstract}

Keywords: Agency Cost, Corporate Performance and Return on Equity

JEL Classification: M4, M40, M41, M42, M48, M49

Paper Type: Research

\section{BACKGROUND OF THE STUDY}

Good corporate governance is essential for the economy of a country (Olivera et al., 2016), especially so if it wants to participate in the global capital markets, especially in inducing long-term foreign capital and direct investments. Direct investments also include knowledge transfer, new technologies, professional skills, and others. In general, investors have to be wary of a country's corporate governance structure, especially on its integrity and conformance to international standards of transparency and accountability.

* Corresponding author: E-mail: afiruddin@uum.edu.my 
According to Olivera et al. (2016), the corporate governance policy of a country can significantly influence investment and financing. As such, the corporate governance mechanism has to scrutinize the efficiency of the management allocating the resources in firms. In general, capital needs to be channeled to profitable companies with good corporate governance due to the overall insufficiency in domestic savings, and therefore, corporate governance serves as an effective and objective means to control management in companies and also contributes to efficient allocation of financial resources, which facilitates financial market functions that can further spur the economic development.

In addition, Olivera et al. (2016) also pointed out that there are many mechanisms involved in implementing good corporate governance in a company. One of them is the representation of the boards of directors on behalf of shareholders to monitor the management effectively. It is imperative to have powerful and systematized board of directors so that it can effectively monitor the management in carrying out their duties to attain the strategic goals of the company. In addition, compensation management such as a bonus is also commonly used internally to ensure management acts not for self-interest but to increase shareholders' wealth. Management compensation is typically in the form of a monetary amount such as salary and bonus that are determined based on job performance, as well as in the form of stocks of the company. The compensation in the form of the firm's shares of the company may improve the alignment of interests between managers and shareholders because the managers will also have some degree of ownership in the company.

According to Olivera et al. (2016), ownership concentration, which is defined as the percentage of shares owned by shareholders, is another mechanism in corporate governance. It is postulated that a high level of ownership concentration results in an effective monitoring power by investors over the firm's managerial decisions. Shareholders with substantial shareholding may use their voting power to initiate firm actions and decisions in a company such as the election of board members as well as the replacement of non-performing CEO or lackluster management. With this regard, the essential expectation is that substantial shareholding results in ineffective monitoring of the management by the shareholders, hence lowering the agency cost.

As described by Olivera et al. (2016), good corporate governance encompasses a set of relationships amongst the owners, board of directors, the management, auditors and other stakeholders. These relationships involve various rules and incentives, provide goals and objectives and also determine monitoring performance. Meanwhile, agency cost is a part of corporate governance which is a type of internal company expense that comes from the actions of an agent (management) acting on behalf of a principal (owners or shareholders). Agency cost typically arises in the wake of core disruptions, dissatisfactions and inefficiencies such as conflict of interest between shareholders and management.

Many studies have been conducted related to the relationship between corporate governance and corporation financial performance. Studies by Aggarwal (2013), Fauzi and Locke (2012), and Cheng Wu et al. (2010) found that corporate governance and firm performance are significantly positively related. Yegon et al. (2014), Hastori et al. (2015), Kuutol and Agyemang (2015), McKnight (2006), Sajid Gul et al. (2012), Tariq Aziz et al. (2015) and Garanina et al. (2016) focused on the association between corporate governance and agency cost and showed that corporate governance and agency cost are significantly negatively related, implying that higher director ownership reduces the level agency cost.

There are several studies in the emerging countries that examined the relationship between agency cost and corporate performance. Among them are Alfadhl and Alabdullah (2013) and Jabbary et al. (2013) who studied multi-sector companies in Iraq and Iran, respectively, by using expense ratio and asset utilization as proxies of agency cost. The 
researchers found a significant negative relationship between agency cost and firm performance. Using a sample of listed firms in the Nairobi Stock Exchange and asset utilization ratio to proxy agency cost, Salim (2012) found that there is a significant positive relationship between agency cost and profitability. Meanwhile, in Indonesia, Enni Savitri (2018) utilized a sample of listed Indonesian manufacturing companies with family ownership (percentage \% of share owned by the family) where agency cost (expense ratio) is the independent variable and firm performance (ROA) is the dependent variable. It was found that family ownership and agency costs are significantly related to ROA.

In Malaysia, Nur Syuhada (2014) used multi-sector companies in examining the relationship between firm performance and agency cost. Studies focusing on manufacturing companies are quite lacking. Therefore, this study is conducted to fill the gap by examining the relationship between agency cost and financial performance of public-listed manufacturing firms in Malaysia. Manufacturing companies are selected due to the importance of this sector towards the economic growth of Malaysia and many other countries in the world.

\subsection{Agency Cost and Firm's Performance}

In large businesses, separation of ownership and management is inevitable. Most public listed companies have hundreds of shareholders and it makes it impossible for all shareholders to be involved in the management of the company. Hence, the separation of ownership and management allows shareholders to appoint the management to act on behalf of them to manage the company. However, if managers' objectives are different from shareholders' objectives, it will create agency problems. These problems come with an associated cost, generally referred to as agency costs.

The agency theory offers two options to avoid agency problems. The first option is to develop a structure of governance where the contract based on the agent's behavior to generate agency costs aimed to monitor and assess the act of the agent (Madison 2014). Madison (2014) found that stewardship structures are advantageous for family-owned companies because they increase the steward-like behavior of family employees. Notwithstanding, these structures are damaging because they increase the agent behavior of nonfamily employees. This shows that agency structures based on the agent's behavior are essential, but that stewardship structures can only be useful when a large number of family employees are employed. The second option is to develop a governance structure that can facilitate supervision and appraisal of agent behavior, which typically comprises reporting procedure, the inclusion of the main board of directors or management personnel (Donaldson \& Davis, 1991).

Several ratios can indirectly gauge the agency costs of a firm. Among them are utilization ratio and expense ratio. Total assets turnover is a proxy for utilization ratio that measures the agency cost of a company. This ratio is used to determine management efficiency in utilizing the assets of the company. According to Faisal (2005), the higher the utilization ratio indicates that the assets are used more productively to create value to the shareholders. Meanwhile, another proxy for agency cost, the expense ratio, reflects discretionary management expenses using company resources. Faisal (2005) pointed out that higher management expenses result in higher agency costs.

Higher agency cost indicates poor management of operational cost, which leads to low operating income and is possibly due to fraudulent management of the operating costs. It can increase agency costs and adversely affects the company's profitability (Layyinaturrobaniyah \& Fitriyana 2014). 
According to Kangarlouei et al. (2012), ROA and ROE are the most frequently used financial ratios to ascertain the firm's management overall effectiveness. ROA indicates how well a firm's management is utilizing the assets to create income. Meanwhile, ROE is a profitability ratio that shows the amount of net income a company records as a percentage of the owner's equity.

\subsection{Problem Statement}

In general, agency problem occurs due to the conflicting objectives between managers and shareholders. This problem comes with associated cost normally referred to as agency costs. This cost arises because shareholders are constantly trying to keep the managers focused on pursuing shareholders' interest, with the hope that wealth will be increased accordingly. When a firm has debt, management is attracted to engage in selfish strategies, which results in costly agency costs on the firm and lower the market value of the firm.

According to Mojtahedzadeh (2010), agency costs represent a significant portion of the firm's total costs and shareholders try to ensure the integrity of management activities and by increasing the percentage of management ownership so that agency costs will be reduced. Compared to publicly traded firms, firms in which the managers own 100 percent of the firms have almost zero agency costs. In the other extreme are firms where managers are salaried employees with no equity holding in the firm. In between are companies where the managers own a certain percentage of the firm's total equity.

Separation of shareholders and management creates a conflict if managers act to their self-interest and this leads to the agency problem. According to Vilapour and Khoram (2010), when there is a separation between ownership and management on a firm, there is the potential that managers make decisions that are aligned to their interests instead of the shareholders'. Almost every contractual relationship has an agency problem where the agent promises to perform according to the terms stipulated by the principal. The main problem here is to ensure that the agent performs as promised.

The agency problem does not only occur in the relationship between owners and managers. According to Armour et al. (2009), three generic agency problems may occur in business organizations. Firstly, the agency problem that occurs due to the conflict between shareholders and managers. The problem occurs when the shareholders want to assure that the managers are in-line with the interest of the shareholders instead of carrying out their interests. Secondly, the problem that occurs due to the conflict between majority shareholders and minority shareholders. In this case, majority shareholders act as the agents while the minority shareholders act as the principals. The problem occurs when majority shareholders are pursuing their self-interests at the expense of the minority stockholders. Thirdly, the problem occurs due to conflicts between the management and other stakeholders such as the shareholders, employees, customers and creditors. In this case, the management as an agent may not behave accordingly to other principals such as exploiting workers, expropriating creditors and misleading customers.

In order to reduce agency costs, the law can play an important role. For example, the disclosure requirement for agents can be enhanced and also the principal can enable legal actions being taken towards dishonest or negligent agents (Armour et al., 2009). Furthermore, foreign investors, who are usually minority shareholders, are induced to drive investment of unrelated businesses in the group in order to reduce agency costs. In emerging countries, it is not unusual that many businesses have unrelated diversification due to political, cultural and economic conditions. Usually, both principals and agents are interested to reduce agency costs in any business transaction. Therefore, an effective corporate governance structure has to be established to ensure that creditors and 
shareholders are effectively protected and also to ensure their investment returns. In addition, it also enables to promote the conducive environment to the sustainable growth and efficiency of the corporate sector.

Several studies done by previous researchers have examined the relationship between agency cost and other variables. For example, Atumwa (2013), Nazir et al. (2012), Zakaria et al. (2016), Zheng (2013) determined whether there is a relationship between agency cost and leverage. Meanwhile, Yagon et al. (2014), Hastori et al. (2015), Kuutol and Aqyemang (2015), Tariq Aziz et al. (2015), and Garanina et al. (2016) examined the relationship between agency cost and corporate governance.

Other studies used agency cost proxies such as leverage, the firm's size and company growth and examined their relationship with the firm's performance. Akeem et al. (2014), Abeywardhana (2015), Habib et al. (2016), Idobe et al. (2014) examined the relationship between leverage and firm performance. Niresh and Velnampy (2014), Pervan and Visic (2014), Abbasi and Malik (2015), and Abiodun (2013) established whether the firm's size has a relationship with firm's performance. Loi and Khan (2012), Ting et al. (2014), Yoo and Kim (2015), and Yingler (2015) focused on the relationship between the company's growth and firm's performance.

Alfadhl and Alabdullah (2013) and Jabbary et al. (2013) focused on the relationship between agency cost and firm performance in Iraq and Iran, respectively, and they used expense ratio and asset turnover ratio as proxies of agency cost. Salim Manal (2012) utilized asset utilization ratio as a proxy of agency cost in examining the relationship between agency cost and firm performance. Meanwhile, Enni Savitri (2018) examined the relationship between agency cost and firm performance in Indonesia and used selling, general and administration ratio (SG\&A) to measure agency cost.

Many studies on corporate governance, specifically on the monitoring role of agency cost, have been conducted in different contexts, and agency cost has been proxied by efficiency (assets utilization, assets turnover), expense (SG\&A), leverage, company's growth and company's size. In general, most of them are found to be significant in determining financial performance which is measured by the return on equity (ROE).

\subsection{Significance of the Study}

This study is important from the practical and theoretical points of view. Theoretical importance comes from demonstrating new findings on the relationship between agency cost, proxied by several variables, and firm performance.

The findings are also expected to have practical contributions especially to shareholders, managers and policymakers specifically on formulating mechanisms to reduce agency cost and improve financial performance thus increasing the value of the company in Malaysia, particularly the public-listed manufacturing firms.

Although many studies related to agency costs have been done in Malaysia, hardly any study examined the relationship between agency cost and corporate performance in the public-listed manufacturing companies. The manufacturing sector is chosen in this study due to the importance of the sector towards the growth of the nation's economy thus can aid investors in making investment decisions.

\section{LITERATURE REVIEW}

\subsection{Corporate Governance and Corporate Performance}

Corporate governance is defined as a set of processes, principles and systems that govern a company. It provides the guidelines of how a company can be controlled and guided so 
it can achieve its objectives and goals in a way that adds value to the company and also beneficial for all stakeholders which include the shareholders, board of directors, management, employees, suppliers, customers, and also the community. The efficient allocation of resources will increase corporate performance or profitability. To ensure the efficient allocation of resources, the management should be monitored effectively. There are many mechanisms in order to implement corporate governance in a company. One of the most common mechanisms of corporate governance is the presence of the boards of directors on behalf of shareholders to effectively monitor the management. An organized and strong board of directors is very important for creating effective oversight of the management. Meanwhile, ownership concentration, which refers to the proportion of shares owned by individual investors, is another mechanism in corporate governance More block holder or a higher level of ownership concentration suggests stronger monitoring by the shareholders over firm's managerial decision.

Of late, many researchers are interested in the relationship between corporate governance and corporate performance, but the findings obtained from the studies have been mixed and rather inconclusive. For example, Aggarwal (2013) investigated how corporate governance affects the financial performance of Indian companies using a sample of 20 companies listed on the S\&P CNX Nifty 50 Index and found that governance ratings have a positive and significant impact on the financial performance of the companies. This is in-line with the study by Brown and Caylor (2004) which discovered that companies with better governance record higher profits, are more valuable and payout higher dividends to their stockholders. Cheng Wu et al. (2010) found that firm performance is significantly and negatively related to corporate governance proxies which are board size, CEO duality, stock pledge ratio and deviation voting right. They also found that firm performance has a positive and significant relationship with board independence and insider ownership.

In Ghana, Owusu and Weir (2016) used Ghanaian corporate governance index (GCGI) as a proxy of corporate governance and included all listed companies on the Ghana Security Exchange (GSE) over the period of 2000 to 2009 which is practical because the 'Ghanaian Corporate Governance Code' was introduced in 2003. The authors found that the Ghanaian corporate governance index (GCGI) and firm performance are significantly and positively related. The results indicate the proof of a significant increase in the degree of compliance with the '2003 Ghanaian Corporate Governance Code'. The introduction of the '2003 Ghanaian Corporate Governance Code' has led to improve firm performance. In Malaysia, Ramachandra (2017) used 113 listed companies in Malaysia from 2008 to 2013 and used the corporate governance index of Malaysia (MCGI) as a proxy of corporate governance. The researcher found that firm performance is positively and significantly related to corporate governance, which is measured by the MCGI. The introduction of the Malaysia Code on Corporate Governance (MCCG, 2007 and 2012) gives an effect on the performance of the listed companies in Malaysia. Corporate governance sample firms show marked improvements after implementation of MCCG 2012 as compared to MCCG 2007.

In another angle, Vu and Nguyen (2017) used the dual role CEO, the board size, and board independence as proxies of corporate governance and included 137 firms listed on the Singaporean Exchange (SGX) from 2013 to 2016 to investigate the relationship between corporate governance and financial performance. The findings show that board size and firm performance are negatively related. However, board independence and CEO duality are not significantly related to firm performance. Zaid Saidat et al. (2019) studied non-family-owned and family-owned companies to investigate the relationship between corporate governance and financial performance of non-financial companies listed on the Amman Security Exchange (ASE) from 2009 to 2015. They used the size of the board, 
CEO duality and the number of independent directors as proxies of corporate governance and return on assets and Tobin's $Q$ as indicators of financial performance. The findings show that board size is significantly and negatively related to the performance of familyowned firms but is not significantly related to financial performance. There is a strong association between corporate performance and the number of independent directors in family-owned firms. The findings also indicate that ownership concentration has a significant association with financial performance; while in family-owned firms, it has a negative and significant association with Tobin's $Q$.

\subsection{Corporate Governance and Agency Cost}

Corporate governance is the mechanism to resolve agency problem through a system in which companies are controlled and directed and is primarily concerned with the management and stewardship issues. It also involves the accountability of the individuals through a system that minimizes the principal-agent problem in the company, thus it also, directly and indirectly, reduces agency costs in the company.

The impact of corporate governance on agency cost has been of considerable interest to financiers, economists, behavioral scientists, legal practitioners, and business operators. Yegon et al. (2014) used board size, director ownership, institutional ownership, external ownership, CEO duality, remuneration structure and board independence as corporate governance proxies and used asset utilization to measure agency cost. They sampled 9 service companies based on market capitalization from Nairobi Security Exchange (NSE) from 2008 to 2012. They found that higher director and institutional ownership decreases the level of agency cost; smaller board size results in lower agency cost; board independence is positively related to asset utilization ratio and the separation of the post of CEO and chairman and higher remuneration reduce the agency cost.

\section{METHODOLOGY}

\subsection{Conceptual Framework}

Figure 1 shows the conceptual framework of the study.

Independent Variables

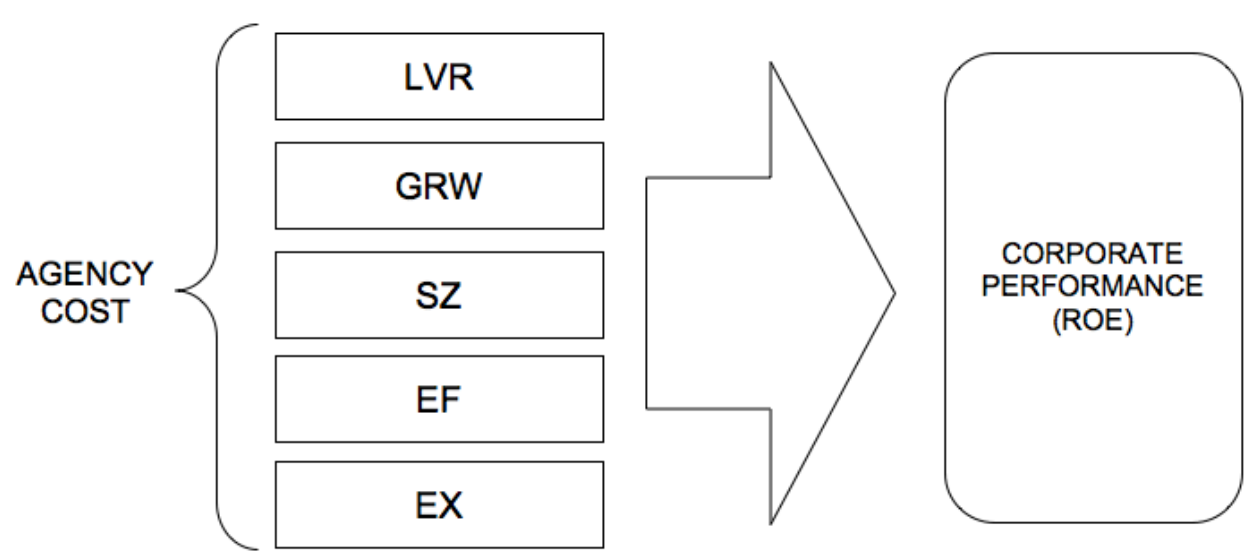

Figure 1.Conceptual Framework

Note: $L V R=$ Leverage, $G R W=$ Growth, $S Z=$ Size, $E F=$ Efficiency, $E X=$ Expenses, $R O E=$ Return on Equity 


\subsection{Research Design}

According to Dooley (2007), a research design is an outline that is used to give an answer to the research problem. The data in this study was collected from Bursa Malaysia, covering the period of 2012 to 2016 . This study adopts a quantitative research design by using secondary data. Regression analysis is applied in this study because the objective of this study to determine the relationship between leverage, firm's growth, firm size, efficiency and expense on corporate performance.

\subsection{Data Collection}

The study utilized secondary data from companies listed in Bursa Malaysia. Secondary data ensure the precision and accuracy of data other than via questionnaires and interviews (Sekaran, 1992; Yaacob, 2011).

It covers all the eleven sectors classified in the manufacturing industry that are established by the Malaysian Investment Development Authority (MIDA). To increase the reliability and validity of the findings, audited financial statements of the companies selected were used. The secondary data collected were revenue, expenses, assets, liabilities and equity. They are credible and reliable because they were audited by professional external auditors.

The population of this study covers manufacturing companies listed in Bursa Malaysia for the period from 2011 to 2016. According to Choong (2016), there are 11 sectors classified in the manufacturing industry that was made in accordance with the criteria established by the Malaysian Investment Development Authority (MIDA). The category classifications of the companies are summarized in Table 3.5.

\subsection{Analytical Model}

The statistical analysis is to examine if there is a significant relationship between proxies of agency cost (leverage, growth, firm's size, efficiency and expense) and corporate performance. Hence, a multiple regression model or equation is developed to analyze the relationship between agency cost and corporate performance as follows.

ROE $=\alpha+\beta 1$ LEVERAGE $+\beta 2$ GROWTH $+\beta 3$ SIZE $+\beta 4$ EFFICIENCY $+\beta 5$ EXPENSE $+\mathrm{e}$ (error term)

Where,

ROE: Return on Equity (ROE) is an indicator of how profitable a company is relative to its total equity. ROE gives investors, managers or analysts an idea of how efficient a company's management is in using its equity to generate earnings. Return on equity is displayed as a percentage. The ROE in this study is measured by net income divided by the total equity of the company.

\section{RESULT AND DISCUSSION}

\subsection{Descriptive Analysis}

The descriptive analysis helps us to simplify a large number of data. Descriptive analysis is the analysis where that helps to describe, show or summarize data in a meaningful way. However, the descriptive analysis does not help us to make a conclusion regarding any 
hypotheses we might have made. They are simply a way to describe our data. This analysis is very important because it enables us to present the data in a meaningful way which allows simpler interpretation of the data in which we can get information about distribution or spread from the data. Descriptive analysis typically has two general types of statistics that are used to describe the data which is measures of central tendency and measures of spread.

Table 1. Descriptive analysis among variable.

\begin{tabular}{lrrrrrr}
\hline & LEVERAGE & \multicolumn{1}{c}{ SIZE } & GROWTH & EXPENSE & EFFICIENCY & \multicolumn{1}{c}{ ROE } \\
\hline Mean & 0.317872 & 19.36783 & 0.119529 & 0.220807 & 0.970269 & 0.057497 \\
Median & 0.291938 & 19.29813 & 0.043889 & 0.160499 & 0.918093 & 0.069546 \\
Maximum & 2.312677 & 23.84575 & 36.54977 & 6.342474 & 3.206369 & 5.900444 \\
Minimum & 0.01546 & 15.92366 & -0.748525 & 0.01203 & 0.0338 & -13.1028 \\
Std. Dev & 0.191629 & 1.125312 & 1.442025 & 0.308482 & 0.46963 & 0.58754 \\
Skewness & 2.080316 & 0.593518 & 24.86723 & 12.94187 & 1.432771 & -15.8007 \\
Kurtosis & 19.93479 & 3.763296 & 628.6146 & 243.9881 & 6.793848 & 403.6444 \\
Jarque-Bera & 8235.99 & 53.94114 & 10667237 & 1591017 & 612.2084 & 4374354 \\
Probability & 0 & 0 & 0 & 0 & 0 & 0 \\
Sum & 206.6169 & 12589.09 & 77.69372 & $1.44 \mathrm{E}+02$ & 630.6746 & 37.37275 \\
Sum Sq. Dev. & 23.83226 & 821.8457 & 1349.555 & $6.18 \mathrm{E}+01$ & 143.1383 & 224.0371 \\
Observations & 650 & 650 & 650 & 650 & 650 & 650 \\
\hline
\end{tabular}

From Table 1, a total of 650 data from each variable were studied for the 5-year period from 2012 to 2016 . The table shows that from total observation of 650 of variable leverage, the mean is 0.317872 with a standard deviation of 0.191629 . The skewness is a measure of the symmetry of the data whether the data fit into normal bell-curve. Skewness with near to 0 is more symmetry and from the table shows that skewness of leverage stands at 2.080316 which is not symmetrically bell-shaped.

On the other hand, kurtosis is a measure of whether the data are heavy-tailed or lighttailed or a measure of the peakedness or flatness of a curve. The distribution is called normal if kurtosis stands at 3 . The table shows that kurtosis for leverage stands at 19.93479. This shows that leverage has peak distribution $(19.93>3)$.

Meanwhile for variable size which was proxied by natural log $(\ln )$ of the total asset from the table shows that the value for the mean is 19.36783 with standard deviation 1.125312 . The value of skewness for variable size stand at 0.593518 shows that the data nearly symmetry due to the skewness value near to 0 and for kurtosis the value is 3.763296 show that the data have normal tail due to the kurtosis value near to 3.

For variable growth in the table show that the means value stands at 0.119529 with a standard deviation of 1.442025 . The value of skewness is 24.86723 which is not symmetry due to not near to 0 and the value of kurtosis stand at 628.6146 show that the distribution data for growth have peak distribution due to $628.6146>3$. This is because as per the table shows that the minimum value is -0.748525 and the maximum value is 36.54977 which the gap is very high.

While for the expense from the table show that the average value is 0.220807 with a standard deviation of 0.308482 . The value of skewness stands at 12.94187 show that the data distribution not symmetry into normal bell-curve and the value of kurtosis is 243.9881 shows that the data have peak-tail due to more than 3 . The value of kurtosis is high because the gap between data is high which is as per table the value of minimum is 0.01203 and the value of maximum is 6.342474 .

Finally, the mean efficiency which is proxied by the sale divide by total assets is 0.970629 with a standard deviation of 0.46963 . The value of skewness is 1.4332771 which is near to 0 describe that the distribution of the data near symmetry and the value of 
kurtosis is 6.793848 show the data have peak-tail due to more than 3 . The value of kurtosis is high due to the gap between a minimum value and the maximum value is high which is stands at 0.0338 and 3.206369 respectively.

\subsection{Correlation analysis}

Pearson Correlation analysis is used to examine whether multicollinearity exists among regressors or not. The correlation matrix is a method of detecting multicollinearity. The researcher has the argument that a specific point a correlation will be considered as a high correlation. A correlation considers a high correlation when it exceeds 0.8 or 0.9 according to Kennedy (1998). However, according to Brayman and Cramer (2001), the correlation at 0.8 or higher will have the problem of multicollinearity whereas 0.7 is used as a benchmark by Anderson et al. (1999) for serious correlation. Table 2 shows that there are no correlation exceeds 0.8 means that multicollinearity does not exist among regressors in the data.

Table 2. Pearson Correlation Matrix among variables

\begin{tabular}{|c|c|c|c|c|c|c|}
\hline \multirow{2}{*}{$\begin{array}{l}\text { Correlation } \\
\text { Probability }\end{array}$} & \multicolumn{6}{|c|}{ COMPANY } \\
\hline & LEVERAGE & SIZE & GROWTH & EXPENSE & EFFICIENCY & ROE \\
\hline LEVERAGE & 1.00000 & & & & & \\
\hline SIZE & $\begin{array}{r}0.075573 \\
0.0541\end{array}$ & $\begin{array}{r}1.00000 \\
----\end{array}$ & & & & \\
\hline COMPANY GROWTH & $\begin{array}{r}0.065004 \\
0.0978\end{array}$ & $\begin{array}{r}0.072451 \\
0.0649\end{array}$ & $\begin{array}{r}1.00000 \\
-\end{array}$ & & & \\
\hline EXPENSE & $\begin{array}{r}0.006394 \\
0.8707\end{array}$ & $\begin{array}{r}-0.152033^{*} \\
0.0001\end{array}$ & $\begin{array}{r}-0.022564 \\
0.5658\end{array}$ & $\begin{array}{r}1.00000 \\
----\end{array}$ & & \\
\hline EFFICIENCY & $\begin{array}{r}0.285375^{*} \\
0.0000\end{array}$ & $\begin{array}{r}0.039754 \\
0.3115\end{array}$ & $\begin{array}{r}-0.04754 \\
0.2261\end{array}$ & $\begin{array}{r}-0.197966^{*} \\
0.0000\end{array}$ & $\begin{array}{r}1.00000 \\
----\end{array}$ & \\
\hline ROE & $\begin{array}{r}-0.113339^{*} \\
0.0038 \\
\end{array}$ & $\begin{array}{r}0.134777^{*} \\
0.0006\end{array}$ & $\begin{array}{r}0.010873 \\
0.782 \\
\end{array}$ & $\begin{array}{r}-0.007738 \\
0.8439\end{array}$ & $\begin{array}{r}0.04903 \\
0.2119\end{array}$ & $\begin{array}{r}1.00000 \\
-\end{array}$ \\
\hline
\end{tabular}

Table 2 contains the values of Pearson's Correlation among the variables. Return on equity (ROE) has positively correlated with the firm's size, company growth and efficiency. Positively correlated means that every unit increase of independent variables which is the firm's size, company growth and efficiency is predicted to be accompanied by an increase in ROE by $0.13477,0.010873$ and 0.049030 respectively. For variables company growth and efficiency, the relationship with ROE is weak or not significant due to correlation value is 0.010873 or $1.08 \%$ and 0.049030 or $4.90 \%$ respectively.

Meanwhile, return on equity (ROE) have a negative relationship with leverage and expense. This means that every unit increase in independent variables which is leverage and expense is predicted to be accompanied by a decrease in return on equity (ROE) by 0.113339 and 0.007738 . For expense, the relationship with ROE is not significant due to the correlation value is 0.007738 or $0.77 \%$.

This result is in line to the study by Niresh and Velnampy (2014) which found that a weak positive relationship between firm's size and profitability (ROA) and Muscettola (2016) which conclude that there is a negative relationship between debt (leverage) and firm performance which proxied by ROA.

Among the independent variables, the highest correlation was between leverage and efficiency. The degree of collinearity for two variables was 0.285375 . The relationship is positive and significant at 0.285375 means that when leverage moves or changes by 1 unit, efficiency will change by 0.285375 or $28.54 \%$. This result in line with the study by 
Atumwa (2013) which found a significant relationship between leverage and asset utilization (efficiency).

The second highest correlation among independent variables was the correlation between expense and efficiency. The degree of collinearity for two variables was 0.197966 . The relationship between these two variables is negative and significant at 0.197966 means that every unit increase in expense is predicted to be accompanied by a decrease in efficiency by 0.197966 or $19.80 \%$ or vise Versa. This result is the same result found by Aziz (2015) who found that expense ratio is a negative and significant relationship with asset turnover (efficiency).

Meanwhile, the third-highest correlation among independent variables was the correlation between size and expense. Size has a positive relationship with the expense. The degree of collinearity for two variables was -0.152033 . The relationship between these two variables is positive and significant at 0.152033 means that when size change, the expense will change by 0.152033 or $15.2 \%$. The same result found by Aziz (2015) where size has a negative and significant relationship with expense ratio.

Another correlation among independent variables was not significant which are correlation between leverage and size, leverage and company growth, leverage and expense, size and company growth and size and efficiency which have positive and not significant and the correlation value are 0.075573, 0.065004, 0.006394, 0.072451 and 0.039754 respectively. Meanwhile, the correlation between company growth and expense and company growth and efficiency is negative and not significant and the correlation value is -0.022564 and -0.047540 . However, there are no correlation value exceeds 0.8 means that multicollinearity does not exist among variables in the data.

\subsection{Summary of Findings}

This study was conducted with the aim of establishing the relationship between agency cost and corporate performance of manufacturing companies listed in Bursa Malaysia for the period from 2011 to 2016 . To achieve this objective, a regression analysis was conducted whereby corporate performance was regressed against the predictor variables which where leverage, size, growth, expense and efficiency. Data for both the dependent and predictor variables were obtained from Bursa Malaysia (BMSB). The data was then subjected to regression analysis.

The study found that in the model, three out of five proxy of agency costs are significantly related to corporate performance which measured by ROE. The three variables which significantly related to corporate performance (ROE) are efficiency, leverage and size with p-value $0.0226,0.0002$ and 0.0002 respectively as per table 4.5. The other two variables found that not significantly related to corporate performance (ROE) which are company growth and expense with p-value 0.6915 and 0.3871 respectively. Hence the study found that agency cost to be significantly related to corporate performance.

The study also found that there was no multicollinearity and autocorrelation among all the variables tested. Finally, the result in this study found that the data in this study are stationery means that the distribution of the data constant over time, no periodic fluctuation and the data does not change much.

\section{REFERENCES}

Ahmad Rizal Mazlan \& Chong Yuen Leng (2018). The Moderating Effect of Working Capital Management on the Relationship between Working Capital Determinants and Firm Performance. Indian-Pacific Journal of Accounting and Finance (IPJAF), Vol. 2, No. 1, pp: 38-48. 
Andrews Owusu \& Charlie Weir (2016). The Governance-Performance Relationship: Evidence from Ghana. Journal of Applied Accounting Research, Vol. 17, Issue 3, pp: 285-310.

Atif Abbasi \& Qaisar Ali Malik (2015). Firm's Size Moderating Financial Performance in Growing Firms: An Empirical Evidence from Pakistan. International Journal of Economic and Financial Issues, 5(2), 334339.

Babalola Yisau Abiodun (2013). The Effect of Firm Size on Firms Profitability in Nigeria. Journal of Economics \& Sustainable Development, Vol. 4, No. 5.

Bala Ramasamy, Darryl Ong \& Matthew C. H. Yeung (2005). Firm Size, Ownership and Performance in Malaysian Palm Oil Industry. Asian Academy of Management Journal of Accounting and Finance, Vol 1, 81-104.

Charles Yegon, Jane Sang \& Joseph Kirui (2014). The Impact of Corporate Governance on Agency Cost: Empirical Analysis of Quoted Services Firms in Kenya. Research Journal of Finance and Accounting, Vol.5, No.12.

Choong Yuen Leng (2016). The Interaction Effects of Working Capital Management on The Relationship Between Key Determinants of Working Capital and Firm Performance. Universiti Utara Malaysia.

Chrisostomos Florackis (2008). Agency Costs and Corporate Governance Mechanisms: Evidence for UK Firms. International Journal of Managerial Finance, Vol. 4, Issue 1, pp: 37-59.

Faisal (2005). Analysis of Agency Costs, Ownership Structure and Corporate Governance Mechanism in Indonesian. Jurnal Riset Akuntansi 8 (2): 175-190.

Fitriya Fauzi \& Stuart Locke (2012). Board Structure, Ownership Structure and Firm Performance: A Study of New Zealand Listed-Firms. Management Journal of Accounting and Finance, Vol. 8, No.2, 43-67.

Hair, J.F., Black W.C., Babin B.J., \& Anderson R.E. (2010). Multivariate Data Analysis. Seventh Edition. Prentice Hall, Upper Saddle River, New Jersey.

Hassan Jan Habib, Faisal Khan \& Dr. Muhammad Imran Wasir (2016). Impact of Debt on Profitability of Firms: Evidence From Non-financial Sector of Pakistan. City University Research Journal, Vol. 06, No. 01, pp: 70-80.

Hastori, Hermanto Siregar, Roy Sembel \& Tb. N Ahmad Maulana (2015). Agency Cost, Corporate Governance and Ownership Concentration: The Case of Agro-industrial Companies in Indonesia. Asian Social Science, Vol. 11, No. 18.

Hongxia Li \& Liming Cui (2003). Empirical Study of Capital Structure on Agency Cost in Chinese Listed Firms. Nature of Science, 1(1).

Hossein Jabbary, Zohreh Hajiha \& Roghaleh Hassanpour Labeshka (2013). Investigation of the Effect of Agency Cost on Firm Performance of Listed Firm in Tehran Stock Exchange. European Online Journal of Natural and Social Sciences, Vol. 2, No.3(s), pp. 771-776.

Idode Patrick Esiemogie, Adeleke Toyin Mary, Ogunlowore Akindele John \& Ashogbon Oyekan Samuel (2014).

Lawal Babatunde Akeem, Edwin Terer K., Monica Wanjiru Kiyanjui \& Adisa Matthew Kayode (2014). Effect of Capital Structure on Firm's Performance: Empirical Study of Manufacturing Companies in Nigeria. Journal of Finance and Investment Analysis, Vol.3, No. 4, 39-57.

Lawrence D. Brown \& Marcus L. Caylor (2004). Corporate Governance and Firm Performance. Georgia State University.

Layyinaturrobaniyah R \& Fitriyana D (2014). The agency costs of family and non family firms. Siasat Bisnis 18 (2): 169-179.

Marco Muscettola (2016). The Casual Relationship Between Debt and Profitability: The Case of Italy. Athens Journal of Business and Economics.

Maja Pervan \& Josipa Visic (2012). Influence of Firm Size on Its Business Success. Croatian Operational Research Review, Vol. 3.

Mengmeng Zheng (2013). Empirical Research of the Impact of Capital Structure on Agency Cost of Chinese Listed Companies. International Journal of Economics and Finance, Vol. 5, No. 10.

Mian Sajid Nazir, Haris Khursheed Saita and Muhammad Musarrat Nawaz (2012). The Role of Debt in Reducing Agency Cost: Empirical Evidence From Pakistan. Vol. 4, No. 5.

Ming-Cheng Wu, Hsin-Chiang Lin, I-Cheng Lin \& Chun-Feng Lai (2010). The Effect of Corporate Governance on Firm Performance.

Moayad Mohammad Ali Fadhl Alfadhl \& Tariq Tawfeeq Yousif Alabdullah (2013). Determinants of the Managerial

Okwo Ifeoma Mary \& Ugwunta David Okelue (2012). Impact of Firm's Input Costs on Firm Profitability: Evaluation of the Nigerian Brewery Industry. Research Journal of Finance and Accounting, Vol. 3, No. 6.

Oliver Ike Inyiama \& Chukwuani Victoria N (2014). Empirical Investigation of the Interactions Between Firm Size and Firm's Financial Performance: A Study Based on Brewery Sector of Nigeria. Journal of Finance and Bank Management, Vol. 2, No. 3, pp: 53-68. 
Olivera Gjorgieva-Trajkovska, Krume Nikoloski, Blagica Koleva \& Vesna Georgieva Syrtinov (2016). The Role of Corporate Governance in Transition Economies: Contribution and Development. Issue 5/2016.

Padmanabha Ramachandra Bhatt \& R. Rathish Bhatt (2017). Corporate Governance and Firm Performance in Malaysia. The International Journal of Business in Society, Vol. 17, Issue 5, pp. 896-912.

Peter Kwame Kuutol \& Ebenezer Badu Agyemang (2015). Corporate Board Attributes and Agency Cost: Evidence From Listed Companies In Ghana. International Journal of Empirical Finance, Vol. 4, No. 2, 86-96.

Phillip J. McKnight \& Charlie Weir (2009). Agency Cost, Corporate Governance Mechanisms and Ownership Structure in Large UK publicly Quoted Companies: A Panel Data Analysis. The Quarterly Review of Economics and Finance, 49, 139-158.

Pierluigi Santosuosso (2014). Do Efficiency Ratios Help Investors to Explore Firm Performance? Evidence from Italian Listed Firms. International Business Research, Vol. 7, No. 12.

Zaid Saidat, Mauricio Silva \& Claire Seaman (2019). The Relationship Between Corporate Governance and Financial Performance: Evidence from Jordanian Family and Nonfamily Firms. Journal of Family Business Management, Vol. 9, Issue 1, pp: 54-78.

Zahoor Hussain Javed, Huma Rao, Bader Akram \& Muhammad Fayyaz Nazir (2015). Effect of Financial Leverage on Performance of the Firms: Empirical Evidence from Pakistan. SPOUDAl Journal of Economics and Business, Vol. 65, Issue 1-2, pp: 87-95.

Zahra Moeinfar \& Zahra Mousavi (2011). Sustainable Growth Rate and Firm Performance: Evidence from Iran Stock Exchange. International Journal of Business and Social Science, Vol. 2, No. 23.

Zuriawati Zakaria, Noorfaiz Purhanuddin, Chong Tun Pin \& William Choo Keng Soon (2016). Leverage and Agency Cost: Malaysian Construction Listed Companies. International Journal of Management Research \& Review, Vol. 6, Issue 12, No. 3, 1654-1660. 